Article

\title{
Innovation Trajectories and Sustainability in the Food System
}

\author{
Valeria Sodano \\ Department Political Science, University of Naples Federico II, 80131 Naples, Italy; valeria.sodano@unina.it
}

Received: 31 December 2018; Accepted: 23 February 2019; Published: 28 February 2019

\begin{abstract}
The goal of the study is to answer the question of whether the current processes of technological change and innovation within the agri-food system could help to increase its sustainability. Four strands of literature are used to unveil the nexus between sustainability and innovation: models of technical change and innovation, sustainability definitions, agroecology as a science and political movement, and the conceptualization of food regimes. The results indicate that innovation processes in the system follow two innovation trajectories, leading to two different food regimes, with opposite effects on sustainability. Since market forces push towards the less sustainable regime, adequate interventions are required in order to assure the sustainability of the system.
\end{abstract}

Keywords: innovation; sustainability; food regime

\section{Introduction}

The agri-food system has recently undergone profound changes under the thrust of innovations that, until just a few years ago, had been difficult to predict. The twenty-first century system is extremely different from that of the end of the previous century. The technologies developed in the field of genetics, new materials, and communication have in fact revolutionized the way in which food is produced, marketed, and consumed. The very idea of food has changed, turning from that of a trivial consumer good needed to fulfill basic human needs to that of a commodity closely connected to human health, to the preservation of the environment, to social justice, and to the development of new economic activities.

In the face of material changes, there has been limited research effort that attempts to describe and interpret technological changes so as to allow adaptation of the institutional framework in a way that both tackles the negative side effects of innovation (minimizing innovation risks) and allows society to fully benefit from it (maximizing innovation benefits).

Currently, the discourse on innovation in the agri-food system takes for granted that innovation is meant to seek the twofold objective of increasing sustainability whilst meeting the increasing demand for food associated with the rocketing world population [1,2]. That is to say that innovation should help to address the two main grand challenges of our time, i.e., protecting the environment and reaching food security at a global level.

Over the last few years the debate on innovation in the agri-food system has been increasingly associated with the issue of sustainability. In the EU the emphasis on sustainability is part of the rhetorical discourse surrounding environmental issues, which have led to the changing of the wording of EU economic policies without changing the previous sole objective of enhancing growth and competitiveness. In this regard, it is worth noting that in 2012, in the EU budget, the heading "cohesion and competitiveness for growth and employment" was replaced by the heading "sustainable growth".

While governments (such as the EU) and international development agencies (such as the FAO and the OECD) seem to sustain many forms of innovation, ranging from digital technologies and nanotechnologies to local product marketing systems, vertical agriculture, and bio-farming, some 
scholars have shown how conflicts exist among these diverse innovations and how some of them could pose high societal and environmental risks. Two divergent visions of innovation in the agri-food system may be identified: the life science vision, which is consistent with the agro-industrial model and is part of the dominant Western countries' policy discourse, and the perspective of agroecology, which is politically and academically marginalized. These two competing visions have also been indicated as divergent socio-technical paradigms of agricultural innovation [3,4].

This paper seeks to give an account of theoretical approaches and assessment frameworks useful to help answer the question of whether the undergoing innovation processes in the agri-food sector may help increase its sustainability. Four strands of literature are referred to in order to unveil the nexus between sustainability and innovation: models of technical change and innovation, sustainability definitions, agroecology as a science and political movement, and the conceptualization of food regimes. The offered analysis of the proposed topics is genuinely qualitative and descriptive in nature. It does not attempt to offer a complete review of the literature concerning the topics dealt with, nor to identify complete and theoretically robust analytical frameworks. Both such objectives would require a massive research effort that is beyond the resources available to the author. Instead, the work attempts to identify some aspects of the innovation processes in the agri-food sector that would urgently require tackling at the analytical, descriptive, and normative levels. The final goal is to contribute to raising a critical debate on the issue of innovation and sustainability in the agri-food system.

\section{Materials and Methods}

In order to answer the question of whether the current processes of technological change and innovation within the agri-food system could help to increase its sustainability, a tentative framework was built to assess, at a purely qualitative level, the foreseeable contribution of the current innovation processes to the sustainability objective. The framework was built through a joint reading of the concept of sustainability, the theories of technological change and innovation, and the food regime theory. First, the concept of sustainability was briefly reviewed to identify the definition that is generally accepted in the associated literature and commonly shared by scholars, policy makers, and businesses. Secondly, the main theories of technological change were reassumed in order to identify the conceptual tools that would seem more suitable to analyze the current innovation processes in the food system. Thirdly, the concept of a food regime was used to identify the presence in the system of adequate incentives to drive innovation processes towards sustainability goals. The obtained framework has no analytical purposes; it only helps to develop a reliable narrative of how innovation and technical change might possibly push the system towards sustainability. It is merely an attempt to initiate a discourse on the political and institutional changes required for science and technology to serve all people, now and for future generations.

\subsection{Defining Sustainability}

The concept of sustainability has been at the center of the environmental debate since a definition of sustainable development was given by the Brundtland Commission in 1987: "Development that meets the needs of current generations without compromising the ability of future generations to meet their needs and aspirations" [5]. Since then many definitions and conceptualizations of sustainability have been offered in literature. One famous and everlasting concept is that of the Triple Bottom Line (TBL), which is a sustainability-related construct coined by Elkington [6] firmly maintaining that sustainability should be conceived of and assessed with reference simultaneously to the three environmental, economic, and social spheres. Following the TBL, sustainable development has been viewed as the overlapping area among three development dimensions [7]: economic (i.e., economic growth, private profits, market expansion, and externalized costs), ecological (i.e., carrying capacity, sustainable yield, resource conservation, and biodiversity), and community (i.e., local self-reliance, basic human needs, equity, participation, social accountability, and appropriate technology). 
Ethical and political implication of sustainability have also been investigated. Some authors have shown that an ethical pragmatism, rather than universalism, would better accommodate sustainability policy choices [8]. Moreover, while biocentric and ecocentric ethics cannot be totally dismissed without compromising sustainability, it has been argued that an anthropocentric ethic is more likely to find wide social consensus [9]. With respect to the political issue, there is a general agreement on the role of a real participatory democracy, meaning that a community-based bottom-up approach, deliberation and democratic decision making are necessary ingredients for attaining sustainability [8].

Enhancing sustainability has become over time a high priority objective stressed roughly in any strategy and policy plan set out both by public and private institutions (at local, national, and international levels). For instance, transnational companies (TNCs) in their annual reports addressed to their stockholders and stakeholders usually quote their commitment to sustainability, with examples of concrete policies allegedly carried out to make their activities more sustainable [10]. Notwithstanding the will (be it genuine or otherwise) to achieve sustainability goals, the latter are almost never reached either by the private or by the public sector. With respect to public institutions the reason lies in the many trade-offs within the policies meant to pursue sustainability. Generally, economic objectives are inconsistent with not only environmental but also social objectives. Sustainability involves equity (so closely that the two concepts depend upon each other), i.e., fair resource distribution among generations as well as among individuals and nations (and in its broader ecological definition, among different forms of life and ecosystems) at the present time. However, equity is an ethical issue that, at least with reference to orthodox economics, is not part of the economic sphere. At the same time, there is the well-known conflict between economic objectives, such as growth, and environmental objectives, such as constraining polluting production processes.

With respect to the private actors, sustainable objectives should be pursued through consumer and/or corporate social responsibility. That is, consumers and firms, freely, voluntary, and independently from one another, should renounce consumptions and profits in order to avoid adverse effects on society and the environment. It is easy to understand the limits of social responsibility. On empirical grounds it is evident that if economic agents had acted responsibly, we would not been experiencing such high resource and environment depletion. On theoretical grounds it is inconceivable that socio-economic models be built that simultaneously need assumptions of strong rationality and selfishness alongside weak rationality and reciprocity; one must choose, and choosing the second assumption means abandoning the neoclassical approach, a choice that does not yet seem to be on the agenda of the leading economists and policy makers [11].

\subsection{Innovation Theories}

Economic development is based on technological change and innovation. According to neoclassical economics, technology, constituting the very same production functions, is responsible for the production possibilities and for input productivity. It is supposed to be exogenous to the economic sphere, belonging instead to the scientific and societal sphere; as a consequence, economists only have to study the effects of new technologies in terms of new market equilibria; i.e., in terms of level, composition, and price of the production. Nothing is said of the source of innovation. Schumpeter has been considered the first economist to put the technological issue at the center of economic theory. He showed how technological change and, more generally, innovation (through the process of creative destruction) are the vital energy that allows capitalist economies to function and flourish. The Schumpeterian lesson, however, took decades to stimulate the theoretical debate on the topic of technological change. It was only in the 1960s that economists began to carefully analyze the phenomenon of technological change. The first theoretical development was within the neoclassical approach, through the models of induced technological change [12]; such models explained technological change either as demand pull driven or as a response to relative prices of production inputs (technological innovation would allow users to raise the productivity of the input that is becoming scarce and costlier). In the late 1970s and early 1980s, Nelson and Winter, fully 
reaping the legacy of Schumpeter and within the heterodox economic research program, introduced the evolutionary approach. This builds on the behavioral theory of the firm in order to describe technological change as the search for better techniques and the selection of successful innovations by the market, according to a natural technological trajectory [13] or technological paradigm [14]. At the same time that Nelson and Winter, Arthur, and later David developed a third approach [15] to the analysis of technological change, the theory of path dependence, which well applies to technological innovations characterized by network externalities and increasing returns to scale, emerged. Central to this theory is the concept of technological lock-in; once a technology is chosen, even if there are better technologies available, due to positive network externalities, it becomes the best choice for other users as well. Positive network externalities exist if the benefits (or, more technically, the marginal utility) are an increasing function of the number of other users. In the 1980s and 1990s, Freeman and Perez [16] offered a fourth more encompassing narrative of the interrelationships between technological change and economic growth, by elaborating the concepts of technology systems and technological revolutions. A technological revolution represents a shift to a new technological paradigm, where an innovation, which is at the same time radical and generic, spreads to many sectors, giving rise to clusters of derived innovations that form technology systems. The latest revolution, which ushered the system into the current ICT (Information and Communication Technology) technological paradigm, has been determined by the propulsive force of ICTs, and follows the previous petrochemical technology-based revolution. "The technology systems, grouped in a technological revolution, overlap and generate externalities and markets for each other, thus influencing the direction of further innovation. Technological revolutions are clusters of interrelated technology systems that only merit the term 'revolution' because they extend far beyond the boundaries of the new industries they introduce. Such surges of change eventually transform the rest of the economy, elevate the expected level of productivity across the board, rejuvenate mature industries and open new innovation trajectories, not only within the new technologies, but also through their application to rejuvenate all the other industries and activities" [17].

These four approaches stem from the rediscovery that occurred in the 1980s of the old institutionalisms, which led to the development of new research agendas in the field of economics, such as evolutionary economics, neo-institutionalism, and economic sociology. Nevertheless, while all of them accept the three basic pillars of the institutionalist approach (the rejection of methodological individualism, and the acknowledgment of bounded rationality and social embeddedness of the economic activities), they differ with respect to the degree in which they accept putting socio-institutional variables at the very core of the economic inquiry and therefore recognize the importance of ethical (struggle over value judgments) and political (struggle over power detention) choices in driving techno/economic trajectories. In this respect, the fourth approach is the one that goes furthest towards embracing the institutionalist approach. Finally, a fifth approach is to be mentioned, again developed in the context of heterodox economic theories, but more specifically in the context of critical theories in the same vein as Marxist and structuralist perspectives, which flourished in the first half of the twentieth century. Within this approach, Noble [18] and Feenberg [19] have highlighted the political dimension of technology, questioning the ideology of technological determinism and exploring the way in which technological innovation affects and is affected by power relationships within society.

Unlike the limited interest at the theoretical level, at least until the last quarter of the twentieth century, the issue of technological change has instead often been addressed at the policy level. In many countries, there has been an active role of the state in promoting science and research and development $(R \& D)$ activities, the latter being considered key sources of economic development and national economies competitiveness. In particular, the agricultural sector has historically been the target of heavy public investments in R\&D, through specifically dedicated government bodies. In the U.S, The Agricultural Research Service (ARS) of the U.S. Department of Agriculture (USDA), and in the EU the Common Agricultural Policy (CAP) are outstanding examples of such state engagement in 
agricultural research. The U.S. has also funnelled agricultural research funds into less developed countries, helping to establish important international research institutions such as the IRRI in the Philippines, the IITA in Nigeria, the CIMMYT in Mexico, and the CIAT in Columbia. International organizations such as the WB, FAO, and UNDP have also historically engaged in agricultural research with the formation, for example, in 1971 of the CGIAR. However, it is worth noting that in the same period in which a theoretical interest in the issue of technological change and innovation started to flourish, state intervention all over the world started to decline. At the end of the 1980s, the public sector support for both national and international food and agricultural research began to substantially decline $[20,21]$.

\subsection{Food Regime Theories}

The food regime approach has addressed the issue of how the evolution of the agri-food system is inscribed within the larger process of capitalistic accumulation. Even if such approach does not try directly to explain the linkages between sustainability and technological change, it nevertheless uses a transdisciplinary institutionalist-like approach that turns out to be very helpful to that end.

Literature on food regime, inaugurated by Friedmann [22-25], is anchored to the theories of the world system and of regulation and was first elaborated within the research field of international relations and international political economy. Currently, it is an interdisciplinary approach, encompassing the fields of economics, history, politics, sociology, and law [26]. Friedman's basic definition of food regime is "a rule-governed structure of production and consumption on a world scale" [23]; accordingly, a particular food regime is characterized by a hegemonic power that is able "to dictate the rules."

So far, three food regimes have been described: the "Settler-Colonial" regime, spanning between 1870 and 1914, led by Britain with its policy of cheap food; the "Surplus" regime, between 1945 and 1973, led by the United States, which, under the umbrella of food aid programs, invaded their informal empire of postcolonial states with their food surpluses; and the neoliberal food regime (sometimes also referred to as "food from nowhere" regime or "corporate" food regime [27], where the hegemonic powers are no longer nation states but the large TNCs controlling the global food chains. It is with reference to this last regime that the relationship between sustainability and innovation has to be investigated.

The neoliberal food regime has been shaped by the four credos of neoliberalism-deregulation, international trade liberalization, reduction of public expenditure, and privatization-which have produced a new international food order, characterized, inter alia, by [26]: (1) a high level of consolidation at the manufacturer and retail level, with a dramatic rise of corporate power; (2) an international division of labor based on the organizational features of global food commodity chains, with the rise of export zones in the global south and the displacement of independent producers and small scale agriculture; (3) an increasing market differentiation, with low-quality mass products alongside "high-tech/high quality" rich products; (4) new technologies and intellectual property rights as the new frontiers for profit extraction; (5) the accelerated depletion of natural resources, with a global food system increasingly dependent on oil and massively contributing to climate change [28,29].

While the previous regimes were undermined and overcome by changes in the balance of power at the geopolitical level, it is still not clear what will bring the neoliberal regime to its turning point. There are at least three fields where conflicts and a sudden market structure and strategy changes might lead to a regime change.

The first area of conflict is along the food supply chain for the leadership of the marketing channel. A characteristic of the neoliberal regime has been the subversion of competitive equilibria along the marketing channel, with retailers gaining disproportionate bargaining power in vertical relationships with their suppliers; as a consequence, food manufacturers have lost their dominant position, which had previously guaranteed high profits due to the exercise of monopolistic and monopoly power. Currently, retailing chains risk losing their strategic and economic power for the 
benefit of E-commerce companies, which are absorbing a rapidly increasing share of food purchases. Moreover, the new marketing tools that are being created through the use of big data platforms and the associated information technologies could trigger unexpected moves by big players at every stage of the marketing chain; mergers, acquisitions, and strategic alliances at horizontal and vertical levels could dramatically reshape power relationships along the food chain.

The second area of conflict and strategy change is at the top of the food chain, among agriculture input suppliers. Here the traditional division between agro-chemical, seed and farm machinery industries is becoming increasingly blurred. Whereas in the neoliberal regime the genetically modified (GM) seed technology has spurred the takeover of plant breeders by pesticide manufacturers, the new digital and biological technologies could create incentives for conglomerate consolidation, uniting agrochemical, fertilizer, seed and tractor industries [30].

The third area of conflict refers to social preferences and cultural changes and is linked to the ecological awareness that has become widespread in society at large, in public institutions, and in political discourse. In this regard, the popularity of the concept of sustainability represents the material consolidation of a cultural and political path that begins with the first ecological battles of the seventies. It should be noted that the neoliberal regime has seen the simultaneous strengthening of two opposing fronts: on the one hand, the big corporations responsible for major environmental problems and on the other the environmentalist front consisting of public and private organizations engaged in various sectors of society and economy. These two fronts consist of opposite visions of society and life with different ethical values and political views. In order to resist the agribusiness power, the environmentalist front has hinged upon many organizational and cultural experiences: the rise of grassroot movements, such as urban farming or the Via Campesina and the project of Food Sovereignty; new food styles, such as vegetarianism and veganism; new food ethics, such as anti-speciesism; new agricultural production methods, such as organic and biodynamic agriculture; new agricultural-related disciplines, such as agroecology; and new marketing organizations based on environmental and ethical certification, such as fair trade, short supply chains, and consumer groups buying locally produced food.

While the first two areas of conflict are generated by the innovation opportunities given by digital technologies, the third area of conflict is generated by the general acceptance of the criterion of sustainability as a guide for social and economic organization.

Scholars of food regimes have identified the possible trajectories of change stemming from the third above-mentioned conflict, i.e., the one stemming from the sustainability concept. At the global level, Friedman has envisioned the possibility of social movements proposing agroecology and food sovereignty in order to seriously challenge the neoliberal food order, but without giving an accurate account of what the new food regime might look like. At the European level, Levidow [3] has suggested two possible trajectories: a corporate-environmental food regime vs. the agroecological alternative. According to this author, the corporate-environmental food regime could be backed by the two agendas set by the EU under the umbrella of sustainability, the bioeconomy agenda, and the sustainable intensification project; while the first marginalizes agroecology, the second incorporates it as one of the "green" practices, which include biotechnologies and nanotechnologies, meant to pursue sustainability. Whichever agenda is chosen, the corporate-environmental food regime reinforces the neoliberal productivist narrative, promoting technological innovation and thus increasing productivity in view of the rising world population. On the contrary, the agroecological alternative addresses the "feeding a growing population" problem from a larger perspective, recognizing poverty and social inequalities (among genders, classes and races) as well as environmental degradation as the main issues to deal with in order to guarantee universal access to food. In this perspective, the displacement of corporate power over resources and markets, along with socio-political reforms for fostering social justice, is as important as ecological agronomic practices to assure food security. 


\section{Technological Change and Innovation in the Food System}

\subsection{Technological Change and Innovation in the Agri-food System: Where We Are}

Historically, the activities devoted to the production of food have undergone many technological changes. Changes occurred over the last two centuries have been widely studied. Throughout the nineteenth century, the main technological innovations were the horse drawn machines with the introduction of important mechanical innovations such as mowers, mechanical reapers, and threshing machines. Agricultural marketing also underwent major changes with the first canned food entering the market, the rise of commercial agriculture, and the gradually demise of family-oriented farms in more developed countries. At the beginning of the twentieth century animal power was gradually replaced by the new fuel-based sources of energy, with the first prototype of the gasoline tractor built in 1892. In the same period, there were many technological innovations in food processing and marketing, with the introduction of new forms of packaging, the increase of long-distance trade, and the new food retail formats accompanying the ongoing urbanization processes. The major, long-lasting, technological changes of the last century were referred to as the green revolution, based on the use of new highly productive varieties of wheat and the extensive use of chemicals as both fertilizers and pesticides. The green revolution, characterized by capital-intensive production processes, led to an extraordinary increase in productivity. In the USA in 1860, 1 farm work could feed $4-5$ persons, which became 22.8 in 1957 [31]. At the end of the last millennium, biotechnology brought the main technological changes into the agri-food sector, followed in more recent years by nanotechnologies and digital technologies.

While it is easy enough to recall the main technological innovations that have affected the food sector over the past two centuries, it is rather difficult to evaluate their effects on the economic, political, social, and environmental spheres. It is beyond the scope of this paper to even roughly mention some of the literature on the history and the assessment of technological change in agriculture. The focus will be instead on the current processes of innovation and their effects in term of sustainability.

Different strands of literature give slightly different meanings to the word innovation. Here the reference will be to the Schumpeterian definition, which makes a distinction between invention, innovation, and diffusion. While the invention of a new product or process occurs within the techno/scientific sphere, an innovation is an economic fact. When an innovation meets positive economic outcomes a process of diffusion starts; a vast diffusion is what really transforms what was once an invention into a socio/economic phenomenon. Thus, "inventions can occur anytime, but not all of them become innovations and not all innovations diffuse widely $($,$) which means that the world$ of the technically feasible is always much greater than that of the economically profitable (,) and this, in turn, is much greater than that of [the] socially acceptable" [32].

In describing the innovation processes, we also accept the periodization given by Perez for the five technological revolutions that have occurred since 1771, with each revolution leading to a new technological paradigm. After the age of oil and the post-war golden age, which entailed the green revolution at the agri-food system level, at the beginning of the 1970s, the ICT revolution ushered the global socio-economic system into a transitional era. According to Perez [32], this transitional era would hopefully lead to the sustainable, global ICT golden age, i.e., an age where a new period of prosperity is fed by the digital innovations at the technological level and by the endorsement of the sustainability concept at the sociocultural and institutional/policy level. "The aspiration to 'green' combined with the technologies of ICT has resulted in the gradual emergence of what we call a 'smart green lifestyle'" [33].

The last technological revolution occurred simultaneously with a political revolution, the advent of neoliberalism, and a socio-cultural revolution, which brought the environmental issues to the attention of society at large and gave birth to the concept of sustainability.

Given these premises, the innovation processes in the agri-food sector need to be situated in the current ICT technological paradigm and in the current dominant political system (neoliberalism) and with reference to the influence that the concept of sustainability is having at the socio-cultural 
level. It is, however, important to keep in mind that, while digital technologies and neoliberalism have already reached a hegemonic position, sustainability still occupies a marginal position, since it is not a well-accepted concept (nor a guide for policy design) by some sectors of society and is sometimes misunderstood even by those praising it. Moreover, it is also used in deceitful ways by actors, often large companies, trying to "green" their public image.

In what follows, first a presentation of the major agribusiness-driven innovations available for the agri-food sector is offered, showing their possible negative outcomes in terms of sustainability. Secondly, the agroecology alternative is proposed as a possible, more sustainable innovation trajectory. Third, a discussion is offered on how economic organization and competitive equilibria in the food system, and the accelerating innovation processes occurring in the digital technology system, disadvantage agroecology as a viable alternative to an environmental-corporate-led food regime. The concluding remarks contain policy suggestions.

Table 1 presents a list of innovations already adopted or ready to be launched in every stage of the food supply chain. The list does not contain references to agroecology-based innovations, which will be dealt with in the next section. It is generic and presents the innovations most often discussed by the popular press, given that recent reviews are only available for some sectors [34,35].

Table 1. Major agribusiness-driven innovations available for the agri-food sector.

\begin{tabular}{|c|c|c|}
\hline Industries & Innovations & Types \\
\hline \multirow[t]{5}{*}{ Agriculture } & $\begin{array}{l}\text { New techniques of genetic engineering (gene editing } \\
\text { and gene drive through CRISPR-induced alteration). }\end{array}$ & Process/Product, Radical \\
\hline & $\begin{array}{l}\text { ICTs: Smart/precision agriculture (drones; aerial } \\
\text { imaging, spraying, and weeding robots; wireless } \\
\text { sensors to collect data from a field or greenhouse and } \\
\text { to enable automatic cultivation systems; sensors and } \\
\text { ingestible microchip to track cattle's activity levels } \\
\text { and health; autonomous farm vehicles). }\end{array}$ & Process, Radical \\
\hline & Microbial biocontrol agents (Biopesticides). & Process, Incremental/Radical \\
\hline & Genetically modified microbial biocontrol agents. & Process, Radical \\
\hline & $\begin{array}{l}\text { Nanotechnologies (Nanoformulation of } \\
\text { agrochemicals; Nanosensors). }\end{array}$ & Process, Radical \\
\hline \multirow{4}{*}{$\begin{array}{l}\text { Food } \\
\text { manufacturing }\end{array}$} & $\begin{array}{l}\text { Nanotechnologies (packaging, food supplements and } \\
\text { additives, nano antimicrobic cookware). }\end{array}$ & Process/Product, Radical \\
\hline & $\begin{array}{l}\text { Synthetic biology-based nutraceuticals. } \\
\text { ICTs (blockchains for traceability systems; smart }\end{array}$ & Process/Product, Radical \\
\hline & $\begin{array}{l}\text { labels; automatic food processing machines; big data } \\
\text { platforms for procurement and marketing } \\
\text { management). }\end{array}$ & Process/Product, Radical \\
\hline & Animal food made from insects. & Process, Product, Radical \\
\hline Retailing & $\begin{array}{l}\text { ICTs (automatic logistic; in-store analytics; big data } \\
\text { platforms; blockchains for traceability systems; } \\
\text { portable gluten sensors; personalized e-commerce } \\
\text { software and devices). }\end{array}$ & Process/Product, Radical \\
\hline \multirow[t]{2}{*}{ Food service } & Neurogastronomy. & Process/Product, Radical \\
\hline & $\begin{array}{l}\text { ICTs (robot chefs; drone waiters; smart vending } \\
\text { machines; self-dispensing beer and wine machines; } \\
\text { nutritional scanners; smartphones bill payment apps; } \\
\text { mind-reading menus; portable gluten sensors). }\end{array}$ & Process/Product, Radical \\
\hline
\end{tabular}

An analysis of these innovations starting from the extensive literature of economic innovation theory is beyond the objectives of this study. Nonetheless, in the table the quoted innovations are tentatively classified with respect to two widely used criteria of radical (vs. incremental) and product (vs. process) innovation, which are only some of the criteria used within the managerial theories of 
innovation sprouted from the seminal work of Drucker [36]. Radical innovations are those which have significant impacts on market equilibria and economic activity; they may entail high benefits but also high risk and are often the consequence of important scientific and technological advancements. As reported in Table 1, most of the ITCS-related innovations in the food sector tend to present the features of radical more than incremental innovations.

All the listed innovations use at least one of the technologies that have been most affecting the food system in recent years: biotechnologies, nanotechnologies, and digital technologies (the latter including both "hardware" components and software components such as artificial intelligence, blockchains, and big data processing systems). Since progresses in biotechnologies and nanotechnologies also depend on the increasing data processing capabilities, these three areas of innovation may all be considered as three technology systems inscribed within the ICT revolution referred to by Perez.

It is very difficult to ascertain how much these innovations may be able to raise the food system's sustainability, since to that end each of them would require a case-by-case benefit-risk assessment. Nevertheless, it is possible to sketch some possible negative outcomes in terms of sustainability that seem very likely to occur given some innovation risks and the current economic and political situation.

Reviewing digital innovations in agriculture, food processing, distribution, and consumption, Bilali and Allahyari [37] explore the contribution of ICTs to transition towards sustainability along the food chain. They highlight the benefits, in terms of increasing resource productivity, reducing inefficiencies, decreasing management costs, and improving food chain coordination, but also point to drawbacks of ICTs as well as the factors limiting their uptake in agriculture. Providing potential negative impacts of ICTS, they quote: problems of e-waste in rural areas, increasing control of food markets by few multinationals, disconnection between producers and consumers through virtual relations, increasing dependency on technology, and risk of exclusion of small-scale and computer-illiterate producers, especially in developing countries [38-40]. Concerns about the marginalization of small-scale producers have also been raised in literature studying the adoption of precision agriculture technologies (PATs). While PATs can have positive impacts on farm productivity and may help to mitigate greenhouse gas emissions [41], their adoption has been reported to be positively associated with farmers' income, farmers' education, and familiarity with computers and farm [42]."

Innovation risks may arise at environmental, economic, and social levels. Environmental risks are mainly associated with nanotechnologies and biotechnologies. New forms of non-degradable pollutants, a loss of biodiversity, ecosystem disruptions (particularly reported for gene drive technologies), an increased resistance of weeds, soil depletion, potential toxic effects on non-target organisms (for instance in the case of microbial pest control agents (MPCAs)), damage to soil structure and fertility, and a reduction of microbial biomass and diversity are all risks that have been reported for nanotechnologies [43,44] and biotechnologies [45].

Economic risks may be associated with innovations in all three technological areas (bio, nano, and digital) and arise from [46,47] (1) the possible disruption of markets (for traditional products that are replaced by innovative products), (2) the displacement of workers due to a more capital-intensive mode of production, and (3) the further consolidation of food systems, with the largest corporations better able to exploit the profit streams from the patents on the new technologies.

Social risks may be more difficult to perceive. The generally reported social risks associated with the technologization of the food system are: (1) the possible negative health effects (due to the presence of toxic substances-from new materials, additives, bioengineered organisms, and new pesticides-in food and the environment and to the loss of healthy traditional food styles), (2) the loss of food sovereignty by local communities and entire countries, (3) the exacerbation of social injustices due to the uneven distribution of the negative health and economic impacts of new technologies due to gender and social classes inequalities, and (4) the loss of privacy and the decrease of autonomy and self-determination in consumer behavior (in relation to the use of personal data for marketing purposes achievable with digital technologies). 
All of the above-mentioned risks require the implementation of careful risk analysis and management policies by both the public and private sectors. Moreover, the decision about the level of risk to be borne should be taken in a democratic context, with a high degree of knowledge and awareness on the part of citizens and using participatory decision-making tools. Unfortunately, many constraints at political and economic levels all over the world curtail the capability of states and societies to effectively tackle the innovation risks.

At the political level the main obstacle comes from the still lasting neoliberal ideology that has been shaping the world's societies and economies for more than four decades. Deregulation and privatization being its pillars, neoliberalism has renounced the more effective regulatory instruments that can be used to protect society from innovation risks (such as standards, accurate premarket risk assessment, strong liability laws, and so on) and has instead promoted private regulation, which has given corporations the power to set the institutional stage that fits their vested interests instead of social well-being [48].

At the economic level, the current presence of three factors is likely to hinder more than promote risk prevention policies. First, there is the extremely high unequal distribution of wealth, which weakens the ability of most people, striving to meet their basic needs, to fully understand technological risks and to call for adequate prevention measures. Second, there is the fast-rising level of concentration in many economic sectors. This is associated on the one hand with aggressive competitive policies, where the requested speed of innovation leaves no room for careful risk analysis, and, on the other hand, with the preference given to shareholders instead of stakeholders at large, with the goal of inflating the value of companies for merger and acquisition purposes. Third, there is the strong interlinkage between national economies. The trade liberalization of the 1990s and 2000s entailed deregulation choices to eliminate non-tariff barriers, which ended up lowering the level of environmental protection. The recent return to protectionism initiated by the Trump administration seems to make things even worse, disrupting the existing scant international cohesion to cope with global risks. The disappointing results of international climate change negotiations (COP24) held recently in Katowice are an outstanding example of such dynamics.

\subsection{Agroecology as An Alternative Innovation Trajectory for Fostering Sustainability}

The term agroecology was originally used with reference to the application of ecology in agriculture, therefore designating a scientific discipline that somehow merges agronomy and ecology. Agroecological research concerned the comprehension of the interaction between ecosystems and agricultural practices aimed particularly at finding an innovative means of plant protection. From the 1970s, agroecology continued to be defined as a scientific discipline but also emerged as a movement within the then sprouting environmentalist movements [49,50]. Currently, agroecology can be thought of as science, movement, and practice; it aims at a sustainable food system, questioning the agribusiness model with its negative environmental and social impact [51,52]. Agroecological farming practices seek to optimize ecological processes, thus minimizing the need for external inputs by providing an array of ecosystem services such as biodiversity maintenance and soil fertility enhancement [53,54]. Intercropping, agroforestry, wildflower strips, and conservation tillage are examples of agroecological practices that nevertheless, to be effective, need to be adapted in the local context through the development of tailor-made practices integrating general scientific principles with farmers' knowledge of the specific pedoclimatic, social, and economic context. Agroecology is also important for the achievement of the objectives set within the climate-smart agriculture perspective [55].

As a social and political movement, agroecology fights the power of the agribusiness by promoting short food supply chains that reconnect producers and consumers, and therefore food, with agriculture again. Experiences such as community-supported agriculture are considered advanced models for sustainable food systems [56,57]. Agroecology has been described as a technological paradigm alternative to the genetic engineering and ICT paradigm. The two paradigms would differ with respect 
to their objectives (engineering systems vs. engineering plants) and to the scientific paradigm on which they rely (ecology and holism vs. reductionism) [58].

Innovation is at the core of the agroecology project, but the desired innovation processes are very different from those featured by the agribusiness-led model. In the latter, innovation is produced by technologically advanced actors of the food chain, such as the biotechnology, nanotechnology, and machinery industries, and "offered" to the other more traditional actors, such as agriculture and food manufacturing. The agroecology model instead features a process of co-innovation, which combines both scientific and traditional knowledge that complement and reinforce each other. Farmers need to be placed at the very center of such a process of co-innovation, through bottom-up and territorial processes, helping to deliver contextualized innovative solutions to local problems [59]. To that end, it is important to foster knowledge exchange and share practices, and to create opportunities for collaboration and innovation.

As recently stated in an FAO document [60]:

"By enhancing their autonomy and adaptive capacity, agroecology empowers producers and communities as key agents of change. Rather than tweaking the practices of unsustainable agricultural systems, agroecology seeks to transform food and agricultural systems, addressing the root causes of problems in an integrated way and providing holistic and long-term solutions. This includes an explicit focus on social and economic dimensions of food systems. Agroecology places a strong focus on the rights of women, youth and indigenous peoples."

In the same document, FAO recognizes that agroecology has the potentiality to guide countries to transform their food and agricultural systems, to mainstream sustainable agriculture on a large scale, and to achieve Zero Hunger and multiple other SDGs. To this end, the following 10 elements of agroecology should be preserved:

- "Diversity; synergies; efficiency; resilience; recycling; co-creation and sharing of knowledge (describing common characteristics of agroecological systems, foundational practices and innovation approaches).

- "Human and social values; culture and food traditions (context features).

- "Responsible governance; circular and solidarity economy (enabling environment)" [60].

Notwithstanding its high sustainability potential, due to its capability to encompass all three dimensions of sustainability, agroecology might pose two kinds of risks. The first is the economic risk for economic actors (and communities) who choose the slower innovation process proposed by agroecology; these actors could lose competitiveness with respect to actors following the agribusiness model, and even risk being out the market. The second is the environmental risk associated with the slow pace and local specificity of innovation processes; this means that, in the face of the fast and pervasive environmental degradation due, for example, to global warming, agroecological solutions could come too late and be applicable only in some places. On the contrary, the one-bullet solutions proposed by the agribusiness model, whenever effective and devoid of negative side effects, could offer fast solutions in many places. Therefore, the risk exists that staking everything on agroecology could divert research funds and efforts from alternative technological solutions and limit, for instance, the full exploitation of possible nano and biotechnology benefits. In any case, both these risks could be tackled through (1) a regulatory system requiring more risk assessment of new technologies, thus slowing the introduction of agribusiness-led innovations and enabling a level playing field competition between the two innovation models, and (2) assuring that science plays its due role in the co-innovation processes of agroecology, thus also allowing bio-nano and digital technologies to contribute, whenever possible, to the agroecology project.

\section{Moving Forward: The Coming Food Regime}

The sketched characterization of the two described innovation trajectories (the agribusiness-led and the agroecology innovation trajectories) may seem too simplistic and categorical, considering 
that certain technologies such as the use of MBAs can be consistent with both. Nonetheless, such a characterization, which shifts the attention from the type of innovation itself to the actors responsible for innovation, helps to foretell where power will reside in the next food regime and therefore the regime's structural and institutional features. The agribusiness-led innovation trajectory may lead to the environmental-corporate food regime (ECFR), where power would continue to be owned by large corporations. The agroecology innovation trajectory instead may lead to the agroecology food regime (AEFR), where power could be returned to the people.

The ECFR would retain the characteristics of the neoliberal regime but with changes in structure, firms' strategies, and power relations caused by technological innovation (nano, bio, and digital innovations). Processes of deregulation, privatization, and financialization would continue. Trade liberalization would be practiced along with bilateral trade wars. Inequality in wealth distribution would continue to grow. Consolidation processes would continue, but leading actors might change in response to the phenomena of "creative destruction" caused by technological innovation. The food supply chain would probably be led by the companies better able to master the new digital technologies. Food would increasingly be engineered with a growing distance from agriculture and an increasing risk of people losing knowledge of the basic simple processes of food growing and processing. The ECFR would be unlikely to improve sustainability since it would embrace the same unsustainable business-as-usual philosophy, overlooking the environmental and social dimensions of sustainability.

The AEFR, instead, would imply overcoming the neoliberal creed together with many tracts of the neoliberal food regime. It would entail the slowdown of privatization processes by limiting patents, redistributing land property, and ensuring that local communities have the right to decide on the use of the natural resources of their territory, considered as common pool resources. It would also entail the introduction of appropriate regulatory systems to safeguard the environment and protect against the risks of new technologies. A priority would be to reintroduce and maintain knowledge of the food growing and processing methods in order to respect the principles of food sovereignty. The AEFR would probably assure a higher degree of sustainability, since it explicitly endeavors to integrate the three components of sustainability, i.e., economic, social, and environmental. Nevertheless, it would be the less likely food regime to succeed, since the scale pan between its weaknesses and strengths hangs in favor of the weaknesses, which is the opposite of what happens in the case of the ECFR.

Table 2 summarizes the main strengths and weaknesses of the two regimes. What immediately emerges is that the points of strength of the ECFR are associated with phenomena and dynamics that are already operating in the system. A growing consolidation of the system is clearly already occurring. Table 3 reports the top five companies' worldwide market share for agricultural input industries, following the recent Bayer-Monsanto merger. The concentration in these sectors is impressive, but concentration is high towards the bottom of the food chain, with the first four companies controlling $90 \%$ of the grain trade sector and the top 10 companies of the food and beverage processing industries controlling 37.5 share of the world market. Food retailing is also very concentrated in many countries, such as in Germany, with the top four concentration ratio equal to 85\% [30]. However, the most worrying processes of consolidation are those involving vertical integration and conglomerates, which are much less monitored by the antitrust authorities than horizontal concentration [61]. These new processes of consolidation are being spurred by the technologies of the big data platforms. Over the last years, all major companies in the food chain have been storing huge quantities of data and acquiring small software, drone, and digital intelligence companies. At the same time, they have been investing to develop machineries, seeds, and chemicals that may be integrated in data-dependent precision agriculture technologies; as a consequence, there are incentives to intersectoral merges and acquisitions. Farm machinery companies such as John Deere, AGCO, and CNH already have alliances with seed, pesticide, and fertilizer companies; Bayer has alliances with all of the major farm machinery companies and is heavily investing in crop nutrients [59]. Major companies are fighting to control the two hubs stemmed from technological innovation: "the software hub that coalesces the genomics 
information expressed by plant seeds and livestock breeds; [and] the hardware hub, around farm machinery, which can coalesce the data from every production location and forward it whenever it wishes and for whatever use" [62].

Table 2. Weaknesses and strengths of the two food regime models.

\begin{tabular}{|c|c|c|}
\hline & Weaknesses & Strengths \\
\hline $\begin{array}{c}\text { ECFR } \\
\text { (environmental-corporate } \\
\text { food regime) }\end{array}$ & $\begin{array}{l}\text { The economic component of sustainability } \\
\text { predominating over the environmental and the } \\
\text { social components. } \\
\text { Possible low social consensus (social movements } \\
\text { opposing corporate power, sustainability conflict, } \\
\text { low consumer acceptance of } \\
\text { technology-related risks). } \\
\text { Low profitability of the proposed innovations } \\
\text { (failure of the new products). } \\
\text { Clashing interests of food chains actors (conflicts } \\
\text { along the supply chain). }\end{array}$ & $\begin{array}{c}\text { Consolidation, economic and } \\
\text { political power. } \\
\text { Endorsed by neoliberalism. } \\
\text { Integration in the processes of } \\
\text { financialization. } \\
\text { Innovations exploitable through patents. } \\
\text { Market segmentation. } \\
\text { Benefiting from its integration in the current } \\
\text { technology paradigm (network } \\
\text { externalities, scale and scope economies). } \\
\text { Centrality in the current research agenda. }\end{array}$ \\
\hline $\begin{array}{c}\text { AEFR } \\
\begin{array}{c}\text { (agroecology food } \\
\text { regime) }\end{array}\end{array}$ & $\begin{array}{c}\text { Marginalization within the current } \\
\text { technology paradigm. } \\
\text { Marginalization in the current research agenda. } \\
\text { Opposed by neoliberalism. } \\
\text { Not integrated in the processes of financialization } \\
\text { of the economy. } \\
\text { Long period and localized tailor-made innovations. } \\
\text { Innovations not exploitable through patents. } \\
\text { Meeting only a small share of } \\
\text { consumers' preferences. } \\
\text { Low profitability of the proposed innovations. }\end{array}$ & $\begin{array}{l}\text { The environmental and social components } \\
\text { of sustainability predominating over the } \\
\text { economic component. } \\
\text { Possible high social consensus (of the most } \\
\text { politically active part of the population } \\
\text { sensitive to social and } \\
\text { environmental issues). } \\
\text { Possible increase of interest by international } \\
\text { agencies committed to social justice and } \\
\text { environmental protection. }\end{array}$ \\
\hline
\end{tabular}

Table 3. Agricultural industries—-market shares of the top five companies, 2017 (estimates based on recent $M \& A)$.

\begin{tabular}{cccc}
\hline Seed & Agrochemical & Fertilizer & Farm Machinery \\
\hline $\begin{array}{c}\text { Bayer-Monsanto } \\
\text { (Germany) } 33 \%\end{array}$ & $\begin{array}{c}\text { ChemChina-Syngenta } \\
\text { (China) } 23.5 \%\end{array}$ & Nutrien (Canada) $5.5 \%$ & John Deere (USA) 15\% \\
$\begin{array}{c}\text { Corteva Agriscience } \\
\text { (USA) } 21.3 \%\end{array}$ & $\begin{array}{c}\text { Bayer-Monsanto } \\
\text { (Germany) } 22.9 \%\end{array}$ & Yara (Norway) $4.7 \%$ & Kubota (Japan) $9.1 \%$ \\
$\begin{array}{c}\text { ChemChina-Syngenta } \\
\text { (China) } 7.4 \%\end{array}$ & BASF (Germany) $12.4 \%$ & The Mosaic Company & CNH Industrial \\
Limagrin (France) $4.8 \%$ & $\begin{array}{c}\text { Corteva Agriscience } 3.6 \% \\
\text { (USA) } 11.3 \%\end{array}$ & CF Industries (USA) 2.1\% & (Netherlands) $8.2 \%$ \\
KWS (Germany) $3.9 \%$ & FMC (USA) $4.6 \%$ & Israel Chemicals (Israel) $1.6 \%$ & CLAAS (Germany) $3 \%$ \\
$70.4 \%$ & $74.7 \%$ & 17.5\% & $41.4 \%$ \\
\hline \multicolumn{2}{c}{ Source ECT Group, 2018. }
\end{tabular}

New actors are also entering into the supply chain. Venture capital has shown growing interest in new hardware and software agricultural technologies. Famous but unexpected giants like Amazon, Alibaba, Google, Microsoft, and Tencent are extending their activities into the food sector, and powerful financial players like BlackRock and Blackstone already control significant shares of stocks of large companies like Monsanto, Bayer, Dow, DuPont, and Syngenta [63]. The consolidation processes are driven by digital technologies, which means that the ECFR can be considered to be embodied in the current technology paradigm following the ICT revolution. This is another strength of the ECFR because it can take full advantage of the network externalities and scale economies characterizing the diffusion of digital technologies, which leads to a situation of lock-in and path dependence, making the ECFR invigorate and develop through self-reinforcing mechanisms.

Another strength of the ECFR lies in the possibility it could offer to firms to carry out profitable differentiation strategies. Currently, the food market is highly segmented, with a cheap and low-quality food segment, which includes the poorest consumers, and a plethora of high-quality food segments, tailored to wealthy consumers who exhibit a great variety of food preferences, namely for food that is 
defined healthy, fair, vegan, enriched, low-sugar, low-fat, local, organic, fine, gluten-free, exotic, luxury, and so on. Using all the potentiality of big data platforms, powerful food manufacturers and retailers, who have access to a huge amount of information on consumer preferences and food styles, can design a marketing mix that precisely matches the expectations of customers in every targeted segment, with price discrimination policies guaranteeing very high profits.

Lastly the ECFR is consistent with the political belief of neoliberalism, which is still dominant, and with the ongoing process of financialization of the world economy, so it does not encounter any obstacles from the regulatory bodies and the powerful financial institutions, which set the economy's rules.

The same elements that constitute strong points for the ECFR are, with a different sign, weak points for the AEFR. The opposition to corporate power (and therefore to consolidation and financialization processes) and to the extreme capitalistic accumulation endorsed by neoliberalism has placed the AEFR in a position of disadvantage in the current competitive and institutional framework. Contrary to the ECFR, the innovations proposed by the AEFR, which are not integrated within the dominant technology paradigm, do not benefit from positive externalities and scale economies. This, in turn, does not favor their introduction and diffusion. Finally, being tailored on the fulfillment of rights and equity more than on the value of consumers and profitability does not bear fruit, since the AEFR would offer a product variety that more than likely would not meet the consumer preferences that have already been shaped by the neoliberal food regime.

The points of weakness of the ECFR are mainly the area of conflict in the neoliberal food regime stemming from the growing awareness of the environmental problems as well as the diffusion of the principles of sustainability within the society and institutions, which generates opposition to the irresponsible business-as-usual behavior of firms in the food system. Consequently, strict state regulatory policies and low consumer acceptance of technology-related risks might shift the technology trajectory towards agroecology. Another weak point could come from excessively aggressive competitive strategies of companies, which could generate innovation failures and/or financial troubles, changing the course of the innovation trajectory.

A genuine commitment to sustainability is the only element of strength of the AEFR. Compared to the ECFR, which mainly takes into account the economic dimension of sustainability, the AEFR also tries to consider, and maybe even more so, the environmental and social dimensions of the phenomenon. Therefore, it is supported by international agencies having a strong commitment to social justice and environmental protection, as is shown by the recent statements released by the FAO in favor of agroecology [64].

\section{Conclusions}

At first it was the green revolution, where improved seeds, agrochemicals, and mechanization were the driving technologies in the agri-food system. The current technological revolution, instead, is driven by digital technologies, which refers to ICT in its broader meaning, encompassing software-like components, such as AI, big data platforms, and blockchains, and hardware-like components, such as robots, drones, and sensors (electrical, biological, acoustical, and visual sensors, also using bio-nano engineered materials). In a way, GMOs, introduced in the 1990s, were still part of the previous innovation wave that was centered on the introduction of new seeds and chemicals. It is only since the late 2000s that the fast development in genetic engineering and synthetic biology enabled by new digital technologies has spurred the truly revolutionary innovations in the agri-food system.

In this paper, literature focused on sustainability, innovation, and food regimes helped to answer the question as to whether the innovation processes currently occurring in the food system are likely to improve its sustainability.

A tentative answer to such a question is that innovation processes in the system seem to follow two innovation trajectories, leading to two different food regimes, with opposite effects on sustainability. The first trajectory, driven by agribusiness, pushes towards the ECFR; this regime is very similar to the 
previous neoliberal food regime and therefore would probably follow its unsustainable pattern. The second innovation trajectory, driven by the agroecology movement, leads, instead, to the AEFR, which proposes highly sustainable food production and consumption patterns.

Innovation theories and the concept of sustainability both help to understand which forces are pushing towards one or the other regime.

The theory of technology systems and technological revolutions demonstrates that the current innovation processes in the food system, that for the most part belong to the agribusiness-driven trajectory, are situated in the ICT technological paradigm. This means that innovations in the food system are only partly chosen by actors in the system; they are, instead, largely determined by phenomena of network externalities, path dependence, and technology lock-in associated with the establishment of a new paradigm following a technology revolution. The fact that the innovation trajectory leading to the ECFR is fully consistent with the current technology paradigm is the main point of strength of the ECFR.

The concept of sustainability, on the other hand, helps to understand the forces that push towards the AEFR. The AEFR has the chance to succeed in contexts and conditions in which the concept of sustainability becomes deeply rooted in culture and society. In such cases, social forces would bring policy makers to build an institutional framework capable of shifting economic incentives towards the agroecology innovation trajectory, even within the ICT technology paradigm.

The leading economic actors within the food system are thus following an innovation trajectory, available within the ICT technology paradigm, that tends to exacerbate the unsustainable patterns followed by the previous neoliberal regime. The transition to the ICT paradigm is almost complete, and it would be difficult and even detrimental to stop its development. The opportunities offered by digital technologies might serve both the ECFR and the AEFR. Nevertheless, the innovations already visible and those in the pipeline clearly are going to feed corporate power, profit accumulation, and social inequality, with controversial effects on the environment; many technologies that seem to bring clear environmental benefits in the short term might have unexpected negative side effects and high risks in the future, some of which being even global and systemic.

Perez [32] has explained how a technology paradigm shift needs to be accompanied and supported by adequate institutional changes, which implies innovation within the political sphere, to be able to bring as many benefits as possible. Therefore, policy makers should design policy interventions that are adequate to make the ICT paradigm give rise to innovations that serve the agroecology movement and sustainability more than the vested corporate interests. If we examine more in depth the points of strength of the ECFR previously listed in Table 2, it is possible to identify the following fields of intervention.

(1) Strengthening competition policy. Stricter laws should be enacted. More attention should be paid to vertical and intersectoral (conglomerates) M\&As, anticompetitive effects of strategic alliance and collaborative relationships, vertical restraints, and coordination among antitrust authorities of different countries.

(2) Patent laws. These should be revised and adapted to the new technologies and their transnational diffusion and control. The objective should be to find the right equilibrium between their procompetitive effect (incentives to R\&D investments) and their anticompetitive effects (monopoly power and innovation closure effects). International harmonization should be also considered.

(3) Strengthening environmental regulations. The neoliberal deregulation diktat should be overcome. Recovering the role of the state regulator would facilitate the achievement of environmental protection objectives and would also facilitate firms that would face a clear institutional framework. A greater importance should be given to inter-countries harmonization, without excluding the use of non-tariff barriers in the event of regulatory differences.

(4) Technology risk analysis. Technological changes involve many kinds of risks that are systemic and global [65-67]. Negative outcomes may be prevented through effective technology risk analysis. The last technological revolution, together with economic growth, has caused most of the 
environmental problems we are still struggling with today. Compared to the last century, we now have the tools and the knowledge for a more careful assessment and prevention of risks. What is lacking is the political will. An essential element of risk analysis should be the democratization of risk control, which in the first instance requires the knowledge and awareness of citizens. Unfortunately, many technology risks, especially those of social and political nature, are unknown to most people $[68,69]$. In this respect, the public sector should ensure a higher level of education that embraces the knowledge of new technologies and the risks they pose.

(5) Funding public research. Substantial investments in public research are essential to curb the privatization of knowledge that is the basis of many social risks related to technological change.

(6) Poverty alleviation and food security policies based on the principle of food as a human right. Agroecology proposes a multifaced approach to reach global food security while preserving democracy and the environment. Technology is only one element of this approach. Economic justice and gender equality are other important elements. Food security may be achieved without pressing the accelerator on the commercialization of new technologies; it rather requires wealth redistributive policies and the fulfillment of women rights. The same demographic growth can be held back by fighting against poverty and defending the political, civil, and social rights of women. These objectives require cultural and institutional innovations, which require smart and wise human beings well before smart agriculture.

Finally, it is worth stressing that all the interventions suggested require a change in the dominant political belief, i.e., neoliberalism. Such a political revolution is more difficult to achieve than the technology revolution; nevertheless, there is room for a gradual shift that could be triggered by the further spread of the principles of sustainability. For sustainability to influence the political sphere, it is necessary to consider its three dimensions separately and clearly show and communicate the trade-offs that often exist between environmental, social, and economic sustainability objectives. When a trade-off occurs, a political and/or ethical choice is required. The role of the public sector is then to make decisions in a transparent and democratic way, involving all vested stakeholders and the citizens at large. The concept of sustainability has become a blanket that is too large, often serving to cover, instead of unveiling and tackling, environmental and social problems. Most documents by public and private institutions dealing with the environment and technology risk either forget to consider all three dimensions of sustainability or prefer to focus on one instead of the others and, in the case of a trade-off, do not make the politics underlying the choice explicit. Sometimes it would be more convenient to name one sustainability dimension at a time. How sustainability policies may very often pursue one goal at the expense of others should be investigated.

The sustainability assessment of current innovation waves in the food system is an issue, which has been given little attention thus far. This study has the credit of putting the complexity of such an assessment at the foreground and highlights the need to resort to multiple theories and approaches, such as sustainability science, innovation theories, and food regime approaches. An important result of the paper is the identification of the two alternative technology trajectories leading to two food regimes, and the description of the forces that push towards one or the other alternative. Nevertheless, due to its qualitative approach, the study is limited in its scope. Further development and examinations should include, among other things, extensive reviews of ongoing innovations, case studies of sustainability technology assessment, critical text analysis of public documents suggesting technological innovation as a sure way towards sustainability, and analysis of power relations within the system and their effect on innovation choices and sustainability.

Funding: This research received no external funding.

Conflicts of Interest: The author declares no conflicts of interest. 


\section{References}

1. OECD. Analysing Policies to Improve Agricultural Productivity Growth, Sustainably: Revised Framework. 2015. Available online: http://www.oecd.org/agriculture/agricultural-policies (accessed on 20 September 2018).

2. European Commission. A Strategic Approach to EU Agricultural Research Innovation. 2016. Available online: http:/ / ec.europa.eu/programmes/horizon2020 (accessed on 6 September 2018).

3. Levidow, L. European transitions towards a corporate-environmental food regime: Agroecological incorporation or contestation? J. Rural Stud. 2015, 40, 76-89. [CrossRef]

4. Levidow, L.; Birch, K.; Papaioannou, T. Divergent Paradigms of European Agro-Food Innovation. Sci. Technol. Hum. Values 2013, 38, 94-125. [CrossRef]

5. WCED (World Commission on Environment and Development). Our Common Future; Oxford University Press: Oxford, UK, 1987.

6. Elkington, J. Cannibals with Forks-Triple Bottom Line of 21st Century Business; New Society Publishers: Stoney Creek, CT, USA, 1997.

7. Bell, S.; Morse, S. Measuring Sustainability: Learning by Doing; Earthscan: London, UK, 2003.

8. Norton, B.G. Sustainability; The University Chicago Press: Chicago, IL, USA, 2005.

9. Kortenkamp, K.V.; Moore, C.F. Ecocentrism and anthropocentrism: Moral reasoning about ecological commons dilemmas. J. Environ. Psychol. 2001, 21, 261-272. [CrossRef]

10. Sodano, V.; Hingley, M.K. Corporate social responsibility reporting: The case of the agri-food sector. Economia Agro-Alimentare/Food Economy 2018, 20, 93-120. [CrossRef]

11. Sodano, V. Innovation and food system sustainability: Public concerns vs. private interests. In Proceedings of the EAAE Seminar 'System Dynamics and Innovation in Food Networks', Innsbruck-Igls, Austria, 18-22 February 2008.

12. Ruttan, V.W. Induced Innovation, Evolutionary Theory and Path Dependence. Econ. J. 1997, 107, $1520-1529$. [CrossRef]

13. Nelson, R.R.; Winter, S.G. An Evolutionary Theory of Economic Change; Harvard University Press: Cambridge, MA, USA, 1982.

14. Dosi, G. Technological paradigms and technological trajectories. A suggested interpretation of the determinants and directions of technical change. Res. Policy 1982, 11, 147-162. [CrossRef]

15. Ruttan, V.W. The transition to agricultural sustainability. Proc. Natl. Acad. Sci. USA 1999, 96, 5960-5967. [CrossRef] [PubMed]

16. Freeman, C.; Perez, C. Structural crisis of adjustment, business cycles and investment behaviour. In Technical Change and Economic Theory; Dosi, G., Freeman, C., Nelson, R., Silverberg, G., Soete, L., Eds.; Printer Publisher: London, UK, 1988; pp. 38-66.

17. Perez, C. Technological Revolutions and Techno-Economic Paradigms; Working Papers in Technology Governance and Economic Dynamics no. 20; The Other Canon Foundation: Oslo, Norway, 2009.

18. Noble, D.F. Progress without People; Between the Lines: Toronto, ON, USA, 1995.

19. Feenberg, A. Transforming Technology; Oxford University Press: London, UK, 2002.

20. Ruttan, V.W. Changing Role of Public and Private Sectors in Agricultural Research. Science 1982, 216, $23-29$. [CrossRef] [PubMed]

21. Ruttan, V.W. Productivity Growth in World Agriculture: Sources and Constraints. J. Econ. Perspect. 2002, 16, 161-184. [CrossRef]

22. Friedmann, H. International regimes of food and agriculture since 1870. In Peasants and Peasant Societies; Shanin, T., Ed.; Basil Blackwell: Oxford, UK, 1987; pp. 258-276.

23. Friedmann, H. The political economy of food: A global crisis. New Left Rev. 1993, I/197, $29-57$.

24. Friedmann, H. Feeding the empire: Pathologies of globalized agriculture. In The Empire Reloaded; Panitch, L., Leys, C., Eds.; Monthly Review Press: London, UK, 2004.

25. Friedmann, H.; McMichael, P. Agriculture and the state system: The rise and fall of national agricultures, 1870 to the present. Sociol. Ruralis 1989, 29, 93-117. [CrossRef]

26. Sodano, V. Food Policy beyond neo-liberalism. In Sociological Landscape Theories, Realities and Trend; Erasga, D., Ed.; InTech: Vienna, Austria, 2012; pp. 375-402. Available online: http://www.intechopen.com/books / (accessed on 13 November 2018). 
27. McMichael, P. A food regime genealogy. J. Peasant Stud. 2009, 36, 139-169. [CrossRef]

28. Garnett, T. Cooking up a Storm. 2008, Food Climate Research Network. Available online: https://www.fcrn. org.uk/sites/default/files/CuaS_web.pdf (accessed on 12 September 2018).

29. Shiva, V. Soil Not Oil; South End Press: Brooklyn, NY, USA, 2008.

30. IPES-Food. Too Big to Feed: Exploring the Impacts of Mega-Mergers, Concentration, Concentration of Power in the Agri-Food Sector. 2017. Available online: www.ipes-food.org (accessed on 6 October 2018).

31. Rasmussen, W.D. The Impact of Technological Change on American Agriculture, 1862-1962. J. Econ. Hist. 1962, 22, 578-591. [CrossRef]

32. Perez, C. Technological revolutions, paradigm shifts and socio-institutional change. In Globalization, Economic Development and Inequality: An alternative Perspective; Reinert, E., Ed.; Edward Elgar: Cheltenham, UK, 2004; pp. 217-242.

33. Perez, C.; Murray, T. A Smart Green 'European Way of Life': The Path for Growth, Jobs and Wellbeing. BTTR WP 2018-01. Available online: http://beyondthetechrevolution.com/wp-content/uploads/2014/10/BTTR_ WP_2018-1.pdf (accessed on 20 September 2018).

34. Lewrick, M.; Omar, M.; Williams, R., Jr.; Tjandra, N.C.; Lee, Z.-C. Radical and Incremental Innovation Effectiveness in Relation to Market Orientation in the Retail Industry. In Successful Technological Integration for Competitive Advantage in Retail Settings; Pantano, E., Ed.; Business Science Reference: Hershey, PA, USA, 2015; pp. 239-268.

35. Steiner, B.E. A phenomenon-driven approach to the study of value creation and organizational design issues in agri-business value chains. Ec. Agro-Alimentare/Food Economy 2017, 19, 89-118. [CrossRef]

36. Drucker, P. The Practice of Management; Harper: New York, NY, USA, 1954.

37. Bilali, E.; Allahyari, H. Transition towards sustainability in agriculture and food systems: Role of information and communication technologies. Inf. Process. Agric. 2018, 5, 456-464. [CrossRef]

38. Zewge, A.; Dittrich, Y. Systematic mapping study of information technology for development in agriculture (the case of developing countries). Electron. J. Inf. Syst. Dev. Ctries. 2017, 2, 1-25. [CrossRef]

39. Deichmann, U.; Goyal, A.; Mishra, D. Will digital technologies transform agriculture in developing countries? Agric. Econ. 2016, 47, 21-33. [CrossRef]

40. Ali, J.; Kumar, S. Information and communication technologies (ICTs) and farmers' decision-making across the agricultural supply chain. Int. J. Inf. Manag. 2011, 31, 149-159. [CrossRef]

41. Balafoutis, A.; Balafoutis, A.; Beck, B.; Fountas, S.; Vangeyte, J.; Wal, T.; Soto, I.; Gómez-Barbero, M.; Barnes, A.; Eory, V. Precision Agriculture Technologies Positively Contributing to GHG Emissions Mitigation, Farm Productivity and Economics. Sustainability 2017, 9, 1339. [CrossRef]

42. Pierpaoli, E.; Carli, G.; Pignatti, E.; Canavari, M. Drivers of precision agriculture technologies adoption: A literature review. Procedia Technol. 2013, 8, 61-69. [CrossRef]

43. Sodano, V.; Gorgitano, M.T.; Quaglietta, M.; Verneau, F. Regulating food nanotechnologies in the European Union: Open issues and political challenges. Trends Food Sci. Technol. 2016, 54, 216-226. [CrossRef]

44. Pandey, G. Challenges and future prospects of agri-nanotechnology for sustainable agriculture in India. Environ. Technol. Innov. 2018, 11, 299-307. [CrossRef]

45. Jacobsen, S.E.; Sørensen, M.; Pedersen, S.M.; Weiner, J. Feeding the world: Genetically modified crops versus agricultural biodiversity. Agron. Sustain. Dev. 2013, 33, 651-662. [CrossRef]

46. Scrinis, G.; Lyons, K. The emerging nano-corporate paradigm: Nanotechnology and the transformation of nature, food and agri-food systems. Int. J. Sociol. Food Agric. 2007, 15, $22-44$.

47. Invernizzi, N.; Foladori, G.; Maclurcan, D. Nanotechnology's controversial role for the south. Sci. Technol. Soc. 2008, 13, 123-148. [CrossRef]

48. Sodano, V. Food nanotechnologies and policy challenges. Environ. Chem. Lett. 2018, 16, 5-10. [CrossRef]

49. Wezel, A.; Bellon, S.; Doré, T.; Francis, C.; Vallod, D.; David, C. Agroecology as a science, a movement and a practice. A review. Agron. Sustain. Dev. 2009, 29, 503-515. [CrossRef]

50. Dalgaard, T.; Hutchings, N.J.; John, R.; Porter, J.R. Agroecology, scaling and interdisciplinarity. Agric. Ecosyst. Environ. 2003, 100, 39-51. [CrossRef]

51. Guzman, E.S.; Woodgate, G. Agroecology: Foundations in Agrarian social thought and sociological theory. Agroecol. Sustain. Food Syst. 2013, 37, 32-44.

52. Gliessman, S. Agroecology. In The Ecology of Sustainable Food Systems; CRC Press: Boca Raton, FL, USA, 2015. 
53. Altieri, M. Agroecology: The Science of Sustainable Agriculture, 1st ed.; Westview Press: Boulder, CO, USA, 1995; ISBN 1-85339-2952.

54. Hatt, S.; Artru, S.; Brédart, D.; Lassois, L.; Francis, F.; Haubruge, E.; Garré, S.; Stassart, P.; Dufrêne, M.; Monty, A.; et al. Towards sustainable food systems: The concept of agroecology and how it questions current research practices. A review. Biotechnol. Agron. Soc. Environ. 2016, 20, $215-224$.

55. Saja, S.; Torquebiau, E.; Hainzelin, E.; Pages, J.; Maraux, F. The way forward: An agroecological perspective for Climate-Smart Agriculture. Agric. Ecosyst. Environ. 2017, 250, 20-24. [CrossRef]

56. Kremen, C.; Miles, A. Ecosystem services in biologically diversified versus conventional farming systems: Benefits, externalities, and trade-offs. Ecol. Soc. 2012, 17, 40. [CrossRef]

57. Khadse, A.; Rosset, P.M.; Morales, H.; Ferguson, B.G. Taking agroecology to scale: The Zero Budget Natural Farming peasant movement in Karnataka, India. J. Peasant Stud. 2018, 45, 192-219. [CrossRef]

58. Vanloqueren, G.; Baret, P.V. How agricultural research systems shape a technological regime that develops genetic engineering but locks out agroecological innovations. Res. Policy 2009, 38, 971-983. [CrossRef]

59. Douthwaite, B.; Hoffecker, E. Towards a complexity-aware theory of change for participatory research programs working within agricultural innovation systems. Agric. Syst. 2017, 155, 88-102. [CrossRef]

60. FAO. FAO's Work on Agroecology: A Pathway to Achieving the SDGs. 2018. Available online: https:/ / www.rural21.com/uploads/media/rural2018_02-S14-16.pdf (accessed on 12 September 2018).

61. Sodano, V.; Verneau, F. Competition Policy and Food Sector. J. Int. Food Agribus. Mark. 2014, 26, $155-172$. [CrossRef]

62. ETC Group. Blocking the Chain: Industrial Food Chain Concentration, Big Data Platforms and Food Sovereignty Solutions. 2018a. Available online: www.etcgroup.org (accessed on 6 October 2018).

63. ETC Group. BlackRock and a Hard Place Is the Industrial Food Chain Unravelling or Rewinding? ECT Communique. 2018b. Available online: www.etcgroup.org (accessed on 6 October 2018).

64. FAO. Regional Symposium on Agroecology for Sustainable Agriculture and Food Systems in Europe and Central Asia; FAO: Rome, Italy, 2016.

65. Hellstrom, T. Systemic innovation and risk: Technology assessment and the challenge of responsible innovation. Technol. Soc. 2003, 25, 369-384. [CrossRef]

66. Hellstrom, T. New vistas for technology and risk assessment? The OECD Programme on Emerging Systemic Risks and beyond. Technol. Soc. 2009, 31, 325-331. [CrossRef]

67. Heurtebise, J.Y. Global risks: Cause and consequence of the new interactions between science, technology and society. In The Handbook of Global Science, Technology, and Innovation; Filippetti, A., Archibugi, D., Eds.; Wiley-Blackwell: Hoboken, NJ, USA, 2015; pp. 557-574.

68. Miller, C.; Coldicutt, R.; Kitcher, H. People, Power and Technology: The 2018 Digital Understanding Report; Doteveryone: London, UK, 2018; Available online: http:/ / understanding.doteveryone.org.uk/ (accessed on 20 September 2018).

69. O'Neil, K. Weapons of Math Destruction; Broadway Books: New York, NY, USA, 2016.

(C) 2019 by the author. Licensee MDPI, Basel, Switzerland. This article is an open access article distributed under the terms and conditions of the Creative Commons Attribution (CC BY) license (http://creativecommons.org/licenses/by/4.0/). 